THE EFFECT OF CYST(E)INE ON HUMAN PLATELETS. Menichelli A.,Del Principe D.,Di Giulio S., De Matteis W. Dept. of Pediatrics, University of Rome, Rome, Italy.

Cyst(e)ine metabolism is a source of intracellular oxi dant stress(Astler et al, J Clin Invest $76: 567,1985$ ). We studied the cyst(e)ine effect on platelet(plt)suspensions.Catalase activity of plts incubated $60 \mathrm{~min}$ at $37^{\circ}$ ( with $100 \mu \mathrm{M}$ cyst(e)ine, $1 \mathrm{mM}$ 3-amino-1,2,4-triazole(AT), $0.2 \mathrm{mM}$ DL-Buthionine-(S,R)-sulfoximine(inhibitor of glu tathione cycle)and then washed 3 times, was measured po larographycally.P1t aggregation was performed by standard method.Catalase activity(determined by $o_{2}$ generated/mg protein after $\mathrm{H}_{\mathrm{O}}$ addition) was inhibited by about $50 \%$ after cysteine, and ${ }^{2}$ y about $30 \%$ after cystine addition $(n=20, p<0.01)$. Cysteine inhibited by $40 \% \mathrm{plt}$ aggregation, whereas cystine inhibited $2 / 3$ of 20 samples. This effect was partially reversed by externally added cata lase. The partial inhibition of catalase in the presence of AT indicates the production of $\mathrm{H}_{2} \mathrm{O}$ (AT inhibits catalase only in the presence of $\left.\mathrm{H}_{2} \mathrm{O}_{2}\right)^{2}$. our data suggest that cyclic oxidation-reduction of ${ }^{2}$ thiols, of pharmacologic or physiologic interest, may affect glutathionedepleted plts, by producing $\mathrm{H}_{2} \mathrm{O}_{2}$.

86

${ }^{64}$ COPPER-LOADING TEST AS INDICATOR OF ELEVATED LIVERCOPPER, E.G., IN WILSON'S DISEASE.

Van den Hamer, C.J.A. and Hoogenraad, Tj.U.

Interuniversity Reactor Institute, Delft and

University Hospital, Utrecht

The Netherlands

The shape of the curve of $\mathrm{plasma}-64 \mathrm{Cu}$ as function of time after an $i . v$. dose of $0.5 \mathrm{mg}$ of ${ }^{64} \mathrm{Cu}$ yields information about the $\mathrm{Cu}-$ status of the patient. The drop in ${ }^{64} \mathrm{Cu}$ during the first hours post dose is less steep when the exchangeable, mobile $\mathrm{Cu}$ in the post dose is less steep when the exchangeable, mobile Curve 3 versus 2 ; curve 4 versus 5 ). The increase of plasma- ${ }^{64} \mathrm{Cu}$ after $t=5 \mathrm{~h}$ post dose is due to incorporation of ${ }^{64} \mathrm{Cu}$ in the plasma protein ceruloplasmin: lower liver-Cu results in a higher incorporation of ${ }^{64} \mathrm{Cu}$ (curve 1 versus 2). Application of the test to Wilson's disease (especially for early recognition) and some other - in part unexplained metabolic disorders affecting the Cu-metabolism - will be mentioned. A protocol whjch leads to

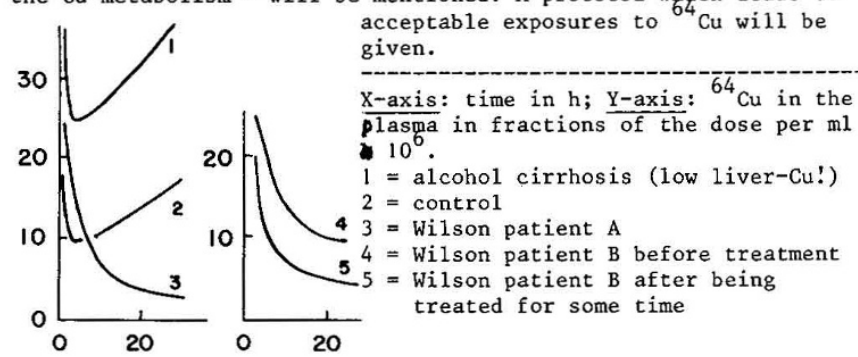

Q 64-COPPER UPTAKE IN FIBROBLASTS IN MENKES' DISEASE

Van den Berg, G.J. and Van den Hamer, C.J.A.

Interuniversity Reactor Institute, Department of

Radiochemistry, Nuclear Biomedical Studies

Mekelweg 15, 2629 JB DELFT The Netherlands

Menkes' (Kinky Hair) Disease, an inborn error of Cu-metabolism, is detectable in in vitro cultured skin fibroblasts. Such cells accumulate significant more $64-\mathrm{Cu}$ from the medium than control cells: the results of 9 otherwise verified patients and of 24 controls illustrate this (see Figure).

Some unusual results of patients will be mentioned, among which one confirmed Menkes patient, which had unusual biochemical characteristics and a patient which had an unknown $\mathrm{Cu}$-deficiency, different from Menkes' Disease.

Some complicating factors of the $64-\mathrm{Cu}$ uptake will be discussed: the influence of confluency of the cultures, $\mathrm{Cu}$ content of the medium and the presence of such $\mathrm{Cu}$ binding ligands as albumin.

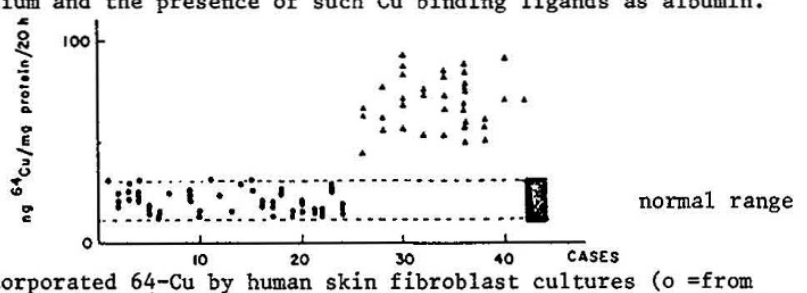

Incorporated $64-\mathrm{Cu}$ by human skin fibroblast cultures $(0=$ from
controls, $\Delta=$ from patients, each symbol represents one culture
88

ZINC BALANCE STUDIES IN BREAST-PED AND FORMULA-FED INFANTS. Sievers, E., Oldigs, H.-D., Schaub, J. Univ. Children's Hospital, Kiel, FRG

It is assumed that zinc absorption from human milk

is better than from formulas. The question arises,

if formulas should be enriched with additional zinc. We studied 10 breast-fed and 5 formula-fed infants in 72-hourbalances undex home conditions. Collecting periods started 2,5 , 8,12 , and 16 weeks postnatally. The formula was supplemented with zinc sulphate and contained $3.98 \mathrm{mg} / \mathrm{l} \mathrm{Zn}$. Zn concentration in faeces, urine and milk samples was determined by atomic absorption spectrometry. The median of $z$ inc values in human milk fell from $3.56 \mathrm{mg} / 1$ in the $3 \mathrm{rd}$ week to $1.2 \mathrm{mg} / 1$ in the $17 \mathrm{th}$ week of lactation.

The median value of zinc intake in breast-fed infants declined from $0.566 \mathrm{mg} / \mathrm{kg} * \mathrm{~d}$ in the third week to $0.151 \mathrm{mg} / \mathrm{kg} \mathrm{d}^{\mathrm{d}}$ in the 17th week. The median value of $\mathrm{Zn}$ intake in bottle fed infants remained between 0.597 and $0.707 \mathrm{mg} / \mathrm{kg} \mathrm{d}^{\mathrm{d}}$ in the 5 collecting periods. Median values of $2 \mathrm{n}$ retention in the breast-fed infants ranged between 0.059 and $0.14 \mathrm{mg} / \mathrm{kg} * \mathrm{~d}$, in the formula-fed infants between 0.043 and $0.306 \mathrm{mg} / \mathrm{kg}^{\star} \mathrm{d}$.

Infants fed a supplemented formula with $3.98 \mathrm{mg} / \mathrm{l} \mathrm{zn}$ have a higher $\mathrm{Zn}$ intake, but approximately the same retention as breast-fed infants. This leads to the conclusion that a formula enriched with zinc (content $3.98 \mathrm{mg} / 1$ ) is equivalent to breast milk concerning zinc retention. Nonenriched formulas contain approximately $1 \mathrm{mg} / \mathrm{l}$ zinc.
COPPER BALANCES IN YOUNG INFANTS AND PRETERMS (BREAST-FED AND BOTTLE-FED). Hōhn, A., Dōrner, $K$., Schaub, J.. Univ. Children's Hospital, Kiel, FRG.

Nutritional copper deficiencies have been described in breast-fed and formula-fed infants, yet balance data are scarce. We compared intake and retention of copper in three groups of infants: breast-fed (I), fed with copper in three groups of infants: breast-fed (I), fed with adapted but not copper-supplemented formula (II) and fed with a supplemented formula. The mean copper concentration of these
milks as determined by wet ashing and atomic absorption spectrometry was in breast-milk (I) $611-1128$ (depending on stage of lactation!), in (II) 121 and in (III) $619 \mu \mathrm{g} / \mathrm{l}$. Five balance periods with 72 hours each were performed in infants during the $3 \mathrm{rd}, 5$ th, 9 th, 12 th and 16 th week resulting in a total of 84 balances. The following mean intakes and retentions ( \pm s.d.) were found (number of balances $=$ ba, number of infants $=$ inf):

$[\mu \mathrm{g} / \mathrm{kg} * \mathrm{~d}]$ I (44 ba/11 inf) II (15 ba/6 inf) III (25 ba/9 inf)

\begin{tabular}{lccc}
\hline intake & $114.5( \pm 22.3)$ & $19.8( \pm 4.2)$ & $106.4( \pm 18.9)$ \\
\hline retention & $88.0( \pm 46.5)$ & $4.6\left(\begin{array}{c}11.5-9.6) \\
\text { (range) }\end{array}\right.$ & $55.5( \pm 20.3)$
\end{tabular}
Similar data were obtained in 21 balances of preterms fed with
both formulas. Conclusion: Bioavailability of copper from breast-milk is best. Nutrition with formula milk unsupplemented with copper does not render a sufficient copper supply.

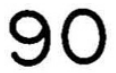

\section{VITAMIN E IS EXPOSED TO OXIDATION IN RED CELL MEMBRANES BUT IS PROTECTED DURING TRANSPORT IN PLASMA.}

Baitella-Eberle,G., Tuchschmid,P., Duc, G. Dept. of Neonatology; Childrens Hospital. University of Zurich, Switzerland

$\alpha$-Tocopherol (Vitamin $E=E$ ) is the only antioxidant of red cell membranes. Its oxidation prevents damage of membrane phospholipids and proteins. E is transported in plasma and delivered to cell membranes by lipoproteins. We compared the oxidation of $E$ in plasma (protein bound) and red cells (membranebound) with $\mathrm{E}$ in aqueous solution (solubilized with Deoxycholate $=$ DOC). An enzymatic radical generating system was used to oxidize E under physiological conditions.

We found E protected completely from oxidation in plasma but sensitive when incorporated in branes. A similar protection was found when $E$ was bound either to serum albumin or to the different purified lipoproteins. It is oxidizable when solubilized in DOC and 4 different oxidation products were characterized by HPLC, one of which could be identified as tocopherylquinone. Similar oxidation products and oxidation rates were found for $E$ in red cell membranes.

These results suggest that $\mathrm{E}$ is easily accessible to oxidation in cell membranes but is protected by protein binding during transport in plasma. 